\title{
A nonlinear model coupling rockfall and rainfall intensity based on a four year measurement in a high Alpine rock wall (Reintal, German Alps)
}

\author{
M. Krautblatter ${ }^{1}$ and M. Moser ${ }^{2}$ \\ ${ }^{1}$ Institute of Geography, University of Bonn, Bonn, Germany \\ ${ }^{2}$ Department of Applied Geology, University of Erlangen-Nuremberg, Erlangen-Nuremberg, Germany
}

Received: 16 December 2008 - Revised: 9 June 2009 - Accepted: 12 June 2009 - Published: 14 August 2009

\begin{abstract}
A total of more than $140000 \mathrm{~kg}$ of smallmagnitude rockfall deposits was measured in eight rockfall collectors of altogether $940 \mathrm{~m}^{2}$ in size between 1999-2003 below a 400-600 m high rock face in the Reintal, German Alps. Measurements were conducted with a temporal resolution up to single days to attribute rockfall intensity to observed triggering events. Precipitation was assessed by a rain gauge and high-resolution precipitation radar. Intense rainstorms triggered previously unreported rockfall intensities of up to $300000 \mathrm{~g} /\left(\mathrm{m}^{2} \mathrm{~h}\right)$ that we term "secondary rockfall event." In comparison to dry periods without frost $\left(10^{-2} \mathrm{~g} /\left(\mathrm{m}^{2} \mathrm{~h}\right)\right)$, rockfall deposition increased by $2-218$ times during wet freeze-thaw cycles and by 56 -thousand to 40 million times during secondary rockfall events. We obtained three nonlinear logistic growth models that relate rockfall intensity $\left[\mathrm{g} /\left(\mathrm{m}^{2} \mathrm{~h}\right)\right]$ to rainfall intensity $[\mathrm{mm} / \mathrm{h}]$. The models account for different rock wall intermediate storage volumes, triggering thresholds and storage depletion. They apply to all rockfall collector positions with correlations from $R^{2}=0.89$ to 0.99 . Thus, the timing of more than $90 \%$ of the encountered rockfall is explained by the triggering factor rainfall intensity. A combination of rockfall response models with radar-supported storm cell forecast could be used to anticipate hazardous rockfall events, and help to reduce the exposure of individuals and mobile structures (e.g. cable cars) to the hazard. According to meteorological recordings, the frequency of these intense rockfall events is likely to increase in response to global warming.
\end{abstract}

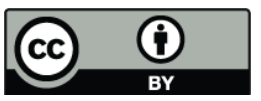

Correspondence to: M. Krautblatter (michael.krautblatter@giub.uni-bonn.de)

\section{Introduction}

Small-scale rockfalls are a major risk in terms of casualties in many mountain environments (Hungr et al., 1999). Historical evidence from the 20th century in the Reintal describe events of up to 7 casualties caused by rockfall related to intense rainstorms (Wehrle, 2004), that may add up to a double digit number over the course of the last century. During the last few years, considerable progress has been made modelling runout tracks of rockfalls of known magnitude (Dorren, 2003). However, the insight that has been gained into the mechanisms that determine the temporal and spatial occurrence of small-scale rock falls is still limited. Especially in locations where temporary exposure to rockfall hazard is inevitable, information on the where and when of rockfall activity is crucial to reduce the vulnerability of individuals and structures.

A number of direct rockfall measurements have been conducted in the past (Rapp, 1960; Caine, 1976; Sommerhoff, 1977; Luckman, 1978; Douglas, 1980; Fahey and Lefebure, 1988; Matsuoka, 1990; Nyberg, 1991; Becht, 1995; André, 1997; Sass, 1998). Whereas these studies provided qualitative evidence for a general rainfall - rockfall relation, no quantitative models were developed, which are crucial for the prediction of the specific hazard. Several authors have promoted the idea that the high discrepancy of rock wall retreat rates encountered in various studies is caused by the fact that different rockfall generating processes were assessed. Douglas (1980), showed that rockfall at his study site in Northern Ireland indicated a steady rate of minor events overlain by a seasonal pattern of higher magnitude events initiated by freeze-thaw activity. Luckman (1976) distinguished geological factors that initially influence type, spatial distribution

Published by Copernicus Publications on behalf of the European Geosciences Union. 


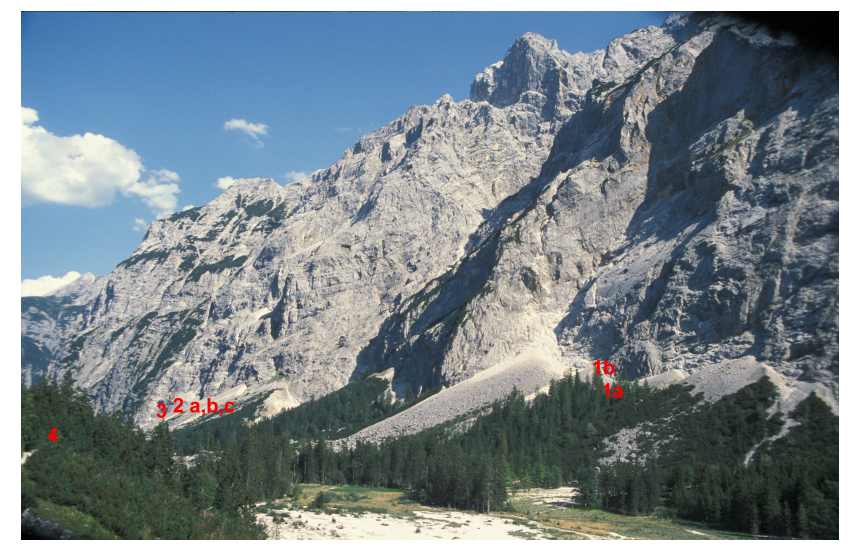

Fig. 1. The 400-600 $\mathrm{m}$ high first ascend of the Reintal North Face ( $\mathrm{N} 47^{\circ} 25^{\prime} ; \mathrm{E} 11^{\circ} 06^{\prime}$ at the left fringe; E $11^{\circ} 04^{\prime}$ at the right fringe). Rockfall collector positions are indicated by number 1a to 4 . Significant intermediate storage is visible on ledges and in couloirs.

and intensity of rockfall activity and climatic factors that finally control rockfall trigger mechanisms. A similar concept was stated by Dorren (2003) who divided up rockfall promoters and factors that cause the actual start of the rockfall movement.

The traditional concept of primary rockfall, which explains rockfall as freshly detached particles from the rock face, is incapable of explaining storage effects and the enormous temporal variability of rockfall deposition. Matznetter (1956) introduced the concept of secondary rockfall that explains the time lag between back-weathering and the actual start of the rockfall deposition (Rapp, 1960; Whalley, 1984). He described the fact that rockfall particles, which are totally detached from the rock face by weathering, can still rest for a long time in intermediate storage or in situ in the rock face until they are removed as a secondary rockfall. This explains why rockfall deposition rates at the foot of the rock wall are (in the short term) often inconsistent with rates of back-weathering. Krautblatter and Dikau (2007) tried to reference the type of output of existing rockfall studies in terms of primary and secondary rockfalls. They developed conceptual mathematical models on basis of empiric measurements. These describe rockfall in respect to promoting pre-weathering and weathering conditions as well as internal and external triggers. They postulate that (i) promoting (pre-weathering and weathering) conditions delimit the speed of back-weathering and (ii) triggering conditions determine rockfall supply while (iii) both are linked by the time-dependent intermediate storage in the structured rock face. This study refers to rockfall supply caused by external triggers under rock walls with high intermediate storage capacity. Thus, the main aim of this article is to provide an empirical model for the nonlinear rockfall response to rainfall valid for prominent alpine rock walls.

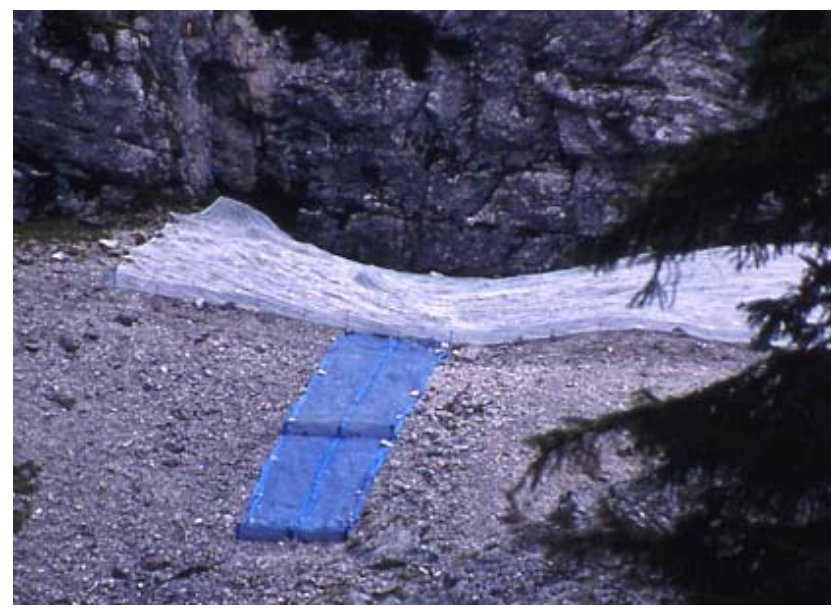

Fig. 2. A $138 \mathrm{~m}^{2}$ rockfall collector at position 3 (in Fig. 1). Steel fences hinder particles from rolling into blue distance nets of $21 \mathrm{~m}^{2}$ size that measure the reduction of rockfall with distance from the rock face.

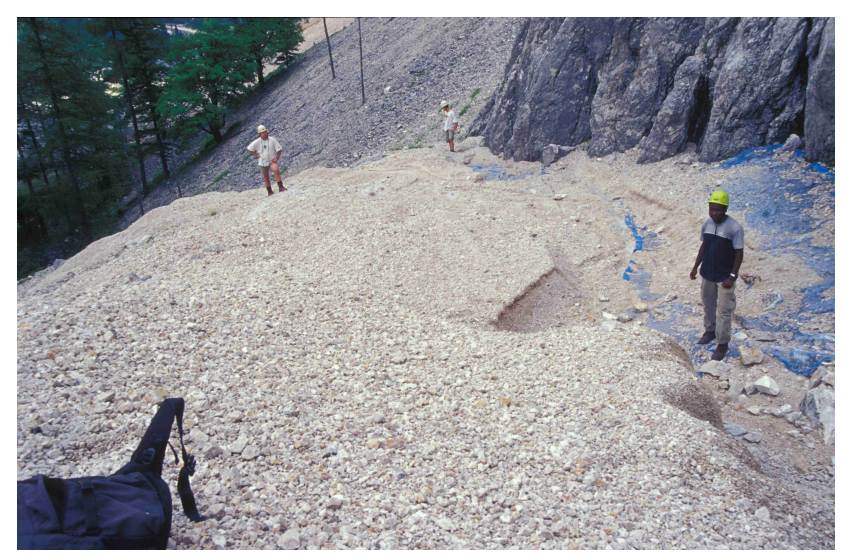

Fig. 3. 56 tons of rockfall $\left(300 \mathrm{~kg} / \mathrm{m}^{2}\right)$ on net 1a were deposited on 14 June 2003 from 07:00 p.m. to 08:00 p.m. by a secondary rockfall event in response to a heavy rainstorm. The blue rockfall net is visible on the right-hand side where rockfall deposits had already been removed. The rucksack and the three people indicate the size of the rest of the net, which is still covered by up to one meter of rockfall deposits.

\section{Study site}

The first ascend of the north face of the Reintal is a 400 $600 \mathrm{~m}$ high rock wall that consists exclusively of Triassic Mid-Wetterstein Limestone, a fine-grained algal limestone (Fig. 1). Its thick bedded structure inherits only relatively small local differences in discontinuity patterns. According to the Selby (1980) scheme, that describes geomorphic rock mass strength on a scale from 0 to 100 , the intact rock strength of the largest part of the Reintal North Face is strong (18), weathering appears to be slightly-moderate (79), spacing of joints ranges between $0.3-3 \mathrm{~m}$ (21-30), joint 
Table 1. A survey of the rockfall collectors of the Reintal.

\begin{tabular}{|c|c|c|c|c|}
\hline Net position number & $\begin{array}{l}\text { Size }\left[\mathrm{m}^{2}\right] \\
\text { in Sept. } 2002\end{array}$ & Specification & Installed & Uninstalled \\
\hline $1 \mathrm{a}$ & 212 & $\begin{array}{l}\text { Sensitive for } \\
\text { secondary rockfall }\end{array}$ & October 2000 & \\
\hline $1 b$ & 21 & Mainly primary rockfall & September 2002 & \\
\hline 1 distance net 1 & 28.5 & $\begin{array}{l}\text { (overhang position) } \\
\text { For the assessment of }\end{array}$ & 2001 & August 2002 \\
\hline & & $\begin{array}{l}\text { "rockfall intensity - distance } \\
\text { from rock face" relation }\end{array}$ & & \\
\hline 1 distance net 2 & 28.5 & See above & 2001 & August 2002 \\
\hline 2 & 234 & Sensitive for secondary rockfall & October 2000 & August 2002 \\
\hline $2 \mathrm{a}$ & 13.5 & Sensitive for secondary rockfall & September 2002 & \\
\hline $2 b$ & 15 & Sensitive for secondary rockfall & September 2002 & \\
\hline $2 \mathrm{c}$ & 11 & Sensitive for secondary rockfall & September 2002 & \\
\hline 3 & 138 & Sensitive for secondary rockfall & October 2000 & \\
\hline 3 distance net 1 & 14.7 & Intensity-distance relation of single rockfall events & September 2002 & May 2003 \\
\hline 3 distance net 2 & 12.25 & Intensity-distance relation of single rockfall events & September 2002 & May 2003 \\
\hline 4 & 90 & $\begin{array}{l}\text { Especially sensitive } \\
\text { for frost-induced rockfall (receives direct sunlight until } \\
\text { the end of October) }\end{array}$ & October 2000 & \\
\hline
\end{tabular}

orientations vary from favourable horizontal values (western part 14) to unfavourable values in the eastern part (5-9), with a small width of joints $<5-20 \mathrm{~mm}(4-7)$ that are continuous with no infill (4-5) and display only a trace to moderate outflow of groundwater (3-5). The overall rock mass strength is, thus, moderate to strong (60-88 out of 100) and relatively homogeneous. The topographic appearance of the rock face is best described by very steep rock steps that are intersected, like in most prominent Alpine rock walls, by high-capacity intermediate storage on ledges and in couloirs in the rock face. Due to the well-developed karst system, permanent hydrologic pressure is nearly absent in the rock face above the scree slopes. The mean annual precipitation ranges between 1600 and $1800 \mathrm{~mm}$ with a pronounced summer maximum due to convective rainstorm activity. Vegetation or animals such as chamois do not affect rockfall measurements significantly because of the extremely steep topography above the rockfall nets.

\section{Methods}

Between 1999-2003 rockfall was continuously measured on twelve robust construction nets installed at eight scree slope positions on the foot of the rock face (Fig. 1). As our study aimed to investigate the impact of certain triggers on rockfall activity, we decided to run measurements on large nets with 11 to $234 \mathrm{~m}^{2}$ to provide a reliable informative basis even for small deposition intensities $\left[\mathrm{g} / \mathrm{m}^{2}\right.$ ] (Fig. 2 and Table 1). The nets were equipped with $60 \mathrm{~cm}$ high steel fences to prevent rocks from rolling out of the net area. Rock particles that fell onto the nets were weighed and removed in all 133 measurements.

Between 1 August and 10 October 2002, the deposition of rockfall particles in the collectors was assessed with a high temporal resolution of one day to two weeks. Measurements were continued on a one to two-monthly basis between 23 May and 16 October 2003. As no extreme rainstorms occurred within the study area between 1999 and 2001, this period was taken as a reference period for average rockfall deposition excluding secondary rockfall events. From 1999 to 2001, nets were measured every few months and yielded low rockfall deposition. Dry frost-free conditions were monitored in summer 2002. The combination of high temporal resolution and direct observation enabled us to link rockfall intensity to certain triggering events such as rainstorms or intense freeze-thaw conditions. The nets were depleted directly after the observed secondary rockfall events and 


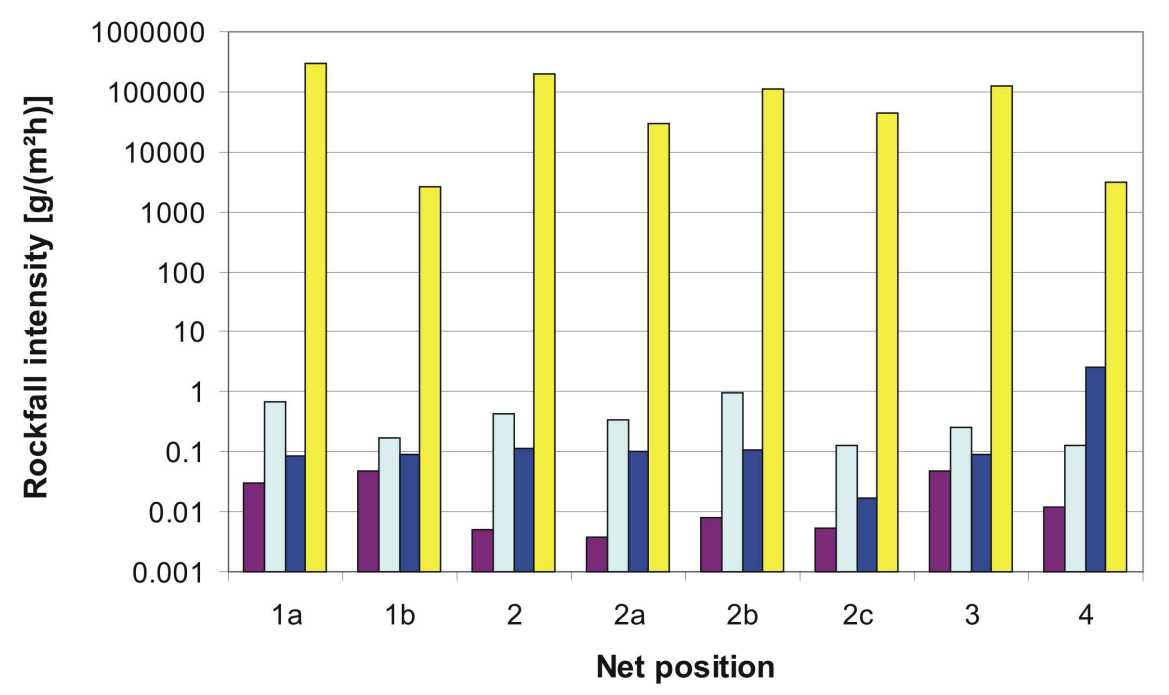

$\square$ Dry summer conditions (no frost action, little or no precipitation)
$\square$ Average value of a year without a rainstorm exceeding $10 \mathrm{~mm} / 30 \mathrm{~min}$
$\square$ Wet freeze-thaw conditions (net 4 recieves direct sun radiation)
$\square$ "Secondary rockfall event" (rainstorm $>13 \mathrm{~mm} / 30 \mathrm{~min}$ )

Fig. 4. Rockfall intensity in response to meteorological conditions. Above all net positions except $1 \mathrm{~b}$ and 4 , a $600 \mathrm{~m}$ high rock face, including prominent intermediate storage on ledges, could act as a source area for rockfall. The rock cliff above net position 4 reached only $400 \mathrm{~m}$ in height and included minor intermediate storages. Net position $1 \mathrm{~b}$ is situated relatively protected under an overhang that was approximately $15 \mathrm{~m}$ high above the net. This figure is based on measurements between 1999 and 2003.

we also performed daily measurements during intense wet freeze-thaw periods (e.g. October 2002) to gain information on maximum intensity of deposition. The increased rockfall response to rainstorms is strictly confined to a time window of less than one hour of surface runoff (see e.g. Wetzel, 1994) in the rock face (Fig. 3). Therefore, $g /\left(\mathrm{m}^{2} \mathrm{~h}\right)$ are the most appropriate unit to quantify and compare rockfall intensity coincident to the duration of triggering conditions. Rockfall materials collected in the nets were composed of single stones measuring up to $40 \mathrm{~cm}$ in length (along one axis) and the falls were, therefore, classified as low-magnitude highfrequency rockfalls, Steinschlag or debris falls according to the nomenclature of Whalley (1984). Some of the nets were supplemented by additional nets at greater distances from the apex of the scree slope in order to calculate the spatial reduction of rockfall with distance from the rock face (Fig. 2). The volumetric importance of intermediate storage was evaluated using air photos and high-resolution photos that were taken horizontally from opposite slope with a telephoto lens.

Precipitation data was obtained from hourly rain gauge measurements at a distance of one to three kilometres from the rockfall nets. Air temperatures were monitored automatically at the same position. The German Seismic Data Analysis Center (SDAC) recorded no earthquakes exceeding a magnitude of $\mathrm{M}_{L}=4.0$ during the examination period which is regarded as the minimum earthquake magni- tude for the activation of rock slides and rockfalls according to Keefer $(1984,2002)$. For a detailed analysis of the rainstorms of 1 August 2002 and 14 June 2003 precipitation radar images from the adjacent meteorological research radar station Hohenpeißenberg and the meteorological station München/Fürholzen with a spatial resolution of two kilometres and a temporal resolution of $15 \mathrm{~min}$ were used to calculate average 30 and $60 \mathrm{~min}$ intensities for the examination area.

\section{Results}

Two types of triggers exert a significant influence on rockfall activity: intense rainstorms and moisture-saturated freezethaw conditions, especially when combined with direct solar radiation during the day (see Fig. 4). For the latter we measured an increase in rockfall intensity $\left[\mathrm{in} \mathrm{g} /\left(\mathrm{m}^{2} \mathrm{~h}\right)\right]$ of 2 to 218 times in comparison to dry conditions without frost. During rainstorms exceeding a threshold of $9-13 \mathrm{~mm} / \mathrm{h}$, the rockfall intensity reached values of $0.68 \mathrm{~kg} /\left(\mathrm{m}^{2} \mathrm{~h}\right)$ to $300 \mathrm{~kg} /\left(\mathrm{m}^{2} \mathrm{~h}\right)$ in all rockfall collectors (Fig. 4 plots the maximum intensity from two events 2002 and 2003). The rainstorms which triggered intense rockfall occurred on 1 August 2002 and on 14 June 2003 lasted less than an hour and appeared on precipitation radar images as one or two central two-kilometrepixels with rainfall intensities of 9 to $38 \mathrm{~mm}$ per $15 \mathrm{~min}$ 
Table 2. Three nonlinear models for rockfall response to rainfall intensity adjusted to topographic conditions and intermediate storage capacity.

\begin{tabular}{|c|c|c|c|}
\hline Rockfall Situation & Rockfall Response Model & Based On Net & Tested For \\
\hline \multicolumn{4}{|l|}{ Model 1: } \\
\hline $\begin{array}{l}\text { Intermediate storage is of minor im- } \\
\text { portance for rockfall } \\
\text { Model 2: }\end{array}$ & $\begin{array}{l}r_{1}=1000000 / \\
\left(1+\exp \left(27.1-1.21 * p_{60}\right)\right)\end{array}$ & $\begin{array}{l}1 \mathrm{~b}, 4 \\
\left(R^{2}=0.99\right)\end{array}$ & $\begin{array}{l}0-3.2 \mathrm{~kg} \mathrm{~m}^{-2} \\
\left(0-18 \mathrm{~mm} \mathrm{~h}^{-1}\right)\end{array}$ \\
\hline $\begin{array}{l}\text { Large intermediate storage, rockfall } \\
\text { protected topography } \\
\text { Model 3: }\end{array}$ & $\begin{array}{l}r_{2}=1000000 / \\
\left(1+\exp \left(17.0-0.78 * p_{60}\right)\right)\end{array}$ & $\begin{array}{l}2 \mathrm{a}, 2 \mathrm{c} \\
\left(R^{2}=0.98\right)\end{array}$ & $\begin{array}{l}0-44 \mathrm{~kg} \mathrm{~m}^{-2} \\
\left(0-18 \mathrm{~mm} \mathrm{~h}^{-1}\right)\end{array}$ \\
\hline $\begin{array}{l}\text { Large intermediate storage, rockfall } \\
\text { exposed topography }\end{array}$ & $\begin{array}{l}r_{3}=1000000 / \\
\left(1+\exp \left(28.1-1.51 * p_{60}\right)\right)\end{array}$ & $\begin{array}{l}1 \mathrm{a}, 3,2 \mathrm{~b} \\
\left(R^{2}=0.89\right)\end{array}$ & $\begin{array}{l}0-300 \mathrm{~kg} \mathrm{~m}^{-2} \\
\left(0-18 \mathrm{~mm} \mathrm{~h}^{-1}\right)\end{array}$ \\
\hline
\end{tabular}

$r_{1}, r_{2}$ and $r_{3}$ calculate the rockfall response in $\mathrm{g} \times \mathrm{m}^{-2}$ to maximum 60-min rainfall intensity ( $p_{60}$ ) for scree slope positions adjacent to the rock face. The models $r_{1}, r_{2}$ and $r_{3}$ are based on 70 high-temporal resolution measurements of more than $100000 \mathrm{~kg}$ of rockfall deposits between 28 June 2002 and 16 October 2003. The value $1000000\left[\mathrm{~g} / \mathrm{m}^{2}\right]$ in the rockfall response function is a hypothetical linear asymptote that describes decoupling of rainfall and rockfall due to storage depletion at unprecedented rainfall intensities.

surrounded by squares with 2 to $8 \mathrm{~mm}$ per $15 \mathrm{~min}$. In comparison to values of rockfall situations without meteorological triggers, secondary rockfall events yielded a 56-thousand to 40-million fold increase in hourly rockfall intensity and thus the deposition exceeded the usual rockfall amount of a whole year without rainstorm by 0.5 to 50 times.

For relating maximum rainfall intensity and rockfall intensity we applied logistic growth functions (Fig. 5 and Table 2). These include assumptions on nonlinear behaviour due to thresholds and storage effects. Threshold effects occur at the transition between usual rockfall deposition and enhanced secondary rockfall deposition. The maximum rockfall intensity in a single event was limited to $1000 \mathrm{~kg} / \mathrm{m}^{2}$ to account for the exhaustion of intermediate storages as rockfall debris sources (Glade, 2005), at least along the pathways of debris-loaded flows. A comparison of the rockfall response functions of individual rockfall collectors revealed that the logistic growth functions of collectors with topographically resembling catchment areas have similar characteristics (see Fig. 5). Therefore, we created three groups of typical rockfall conditions characterized by the influence of intermediate storage and rockfall exposure and combined them to produce three different predictive rockfall response models. Intermediate storage in rock wall sections is categorized as small for a restricted number of low-capacity storages $\left(<2 \mathrm{~m}^{3}\right)$ and as large for coupled high-capacity storages $\left(>10 \mathrm{~m}^{3}\right)$. The term rockfall-exposed refers to conditions that are not sheltered e.g. by a protruding rock bar. The models were optimised using nonlinear regression techniques with a Gauss-Newton estimation of least squares of 70 samples measured in 2002 and 2003.

\section{Discussion}

As reported previously, the combination of high moisture supply and deep freezing leads to a moderate increase in rockfall intensity compared to dry, no-frost conditions (Gardner, 1980, 1983; Sass, 1998). On the other hand, most previous studies did not find a significant correlation between rainfall and rockfall. A comparison of daily precipitation and debris fall activity conducted by Rapp (1960) in Northern Scandinavia did not yield any significant correlation. Luckman (1976) and Gardner (1980) concluded from acoustic rockfall inventories in Canada that few debris falls coincide with certain meteorological conditions. Sandersen et al. (1996) provided evidence for a certain correlation of seven-day rainfall intensities and rockfall in Norway. Sass (1998) showed in a long-term direct rockfall measurement in the German Alps that only rainfall intensities above $30 \mathrm{~mm}$ per day effected a significant correlation. In contrast to previous studies, this study related rockfall activity to hourly and 30-min rainfall intensity. The general mode of rockfall response to short-term rainfall intensity appeared to be similar on all nets. Rainfall intensities up to $10-14 \mathrm{~mm}$ per hour or respectively $9-13 \mathrm{~mm}$ in $30 \mathrm{~min}$ led to no or only a moderate increase in rockfall activity. Rainfall intensities exceeding this range of threshold values triggered secondary rockfall events and thus initiated a sudden increase in rockfall deposition. In response to intense rainstorms we observed a previously undocumented type of rockfall activity, that we term "secondary rockfall event". The term secondary refers to the fact that the rockfall material derives from intermediate storage areas such as wedges and couloirs in the rock face. We observed such events at rainfall intensities that are capable of creating surface runoff and triggered the onset of fluvial processes, hyperconcentrated flows and debris flows on intermediate storage areas in the rock face. These were 


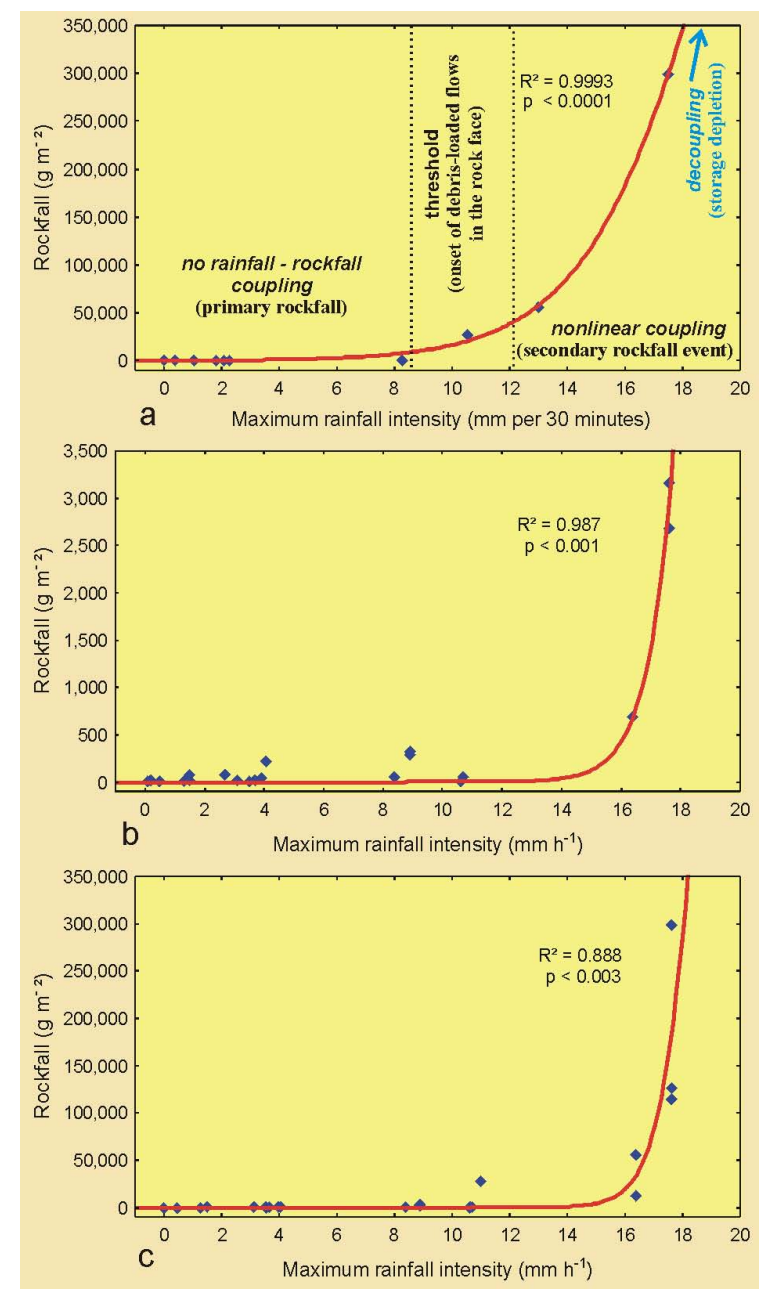

Fig. 5. Rockfall response function of a single net (a) and aggregated rockfall response models $(\mathbf{b}, \mathbf{c})$. Dots refer to individual measurements; the red line indicates nonlinear rockfall response models as presented in Table 2. (a) Rockfall response of net 1a to 30-min rainfall intensity. The rockfall is highly correlated with short-term rainfall intensities and shows a range of threshold values between 9-13 $\mathrm{mm}$ per $30 \mathrm{~min}$, which probably corresponds with the onset of debris-loaded flows in the rock face. (b) Model $r_{1}$ for rockfall conditions with minor importance of intermediate storages, based on nets $1 \mathrm{~b}$ and 4 . (c) Model $r_{3}$ for rockfall-exposed conditions under large intermediate storages, based on nets $1 \mathrm{a}, 2 \mathrm{~b}$ and 3 . The rockfall models $r_{1}$ and $r_{3}$ are based on 52 measurements of more than $100000 \mathrm{~kg}$ on scree slope positions adjacent to the rock face between 28 June 2002 and 16 October 2003 (see Table 2 for detailed information).

described previously by Berti et al. (1999) and Fryxell and Horberg (1943). The mobilized material moved down the several hundred meters high rock cliff as a more or less freefalling particle cloud (Erismann and Abele, 2001). A secondary rockfall event can thus be defined as a short-term mass deposition of fine-grained rockfall material that originates from intermediate storages in the rock wall and is re-

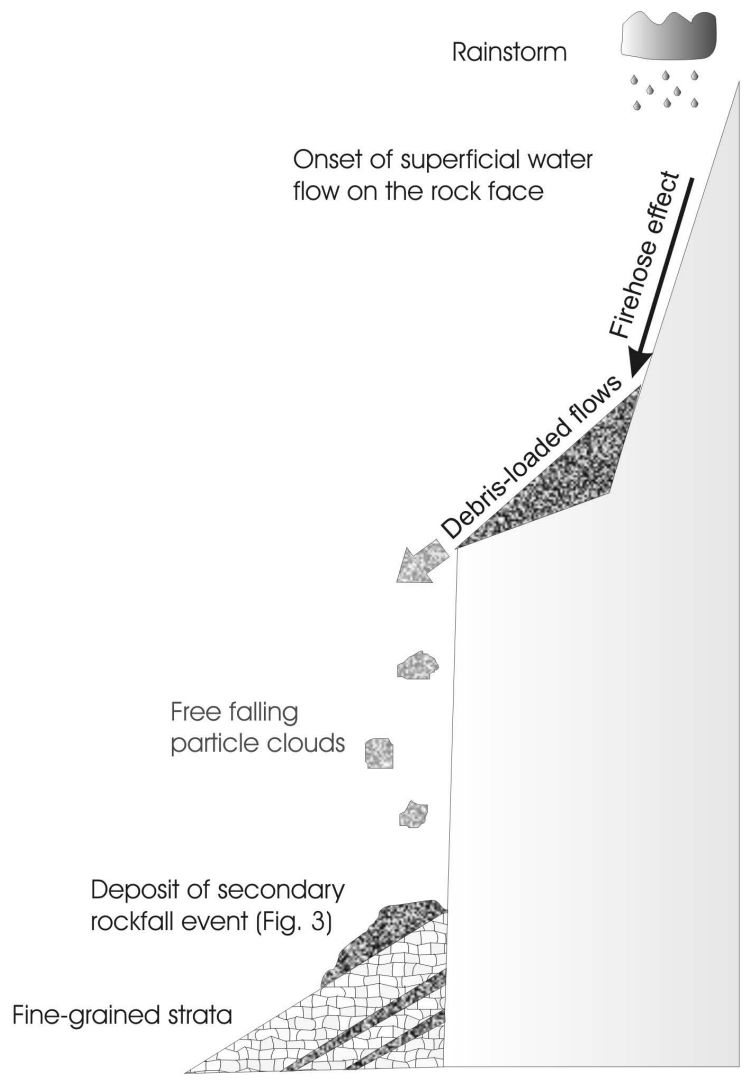

Fig. 6. Scheme of a secondary rockfall event. The firehose effect refers to enhanced debris mobilisation due to high-speed water flow from couloirs onto intermediate storage in the rock face (Fryxell and Horberg, 1943). Particles in intermediate storage are smaller than average rockfall particles due to "kinematic sieving" (Carniel and Scheidegger, 1974), as smaller particles get trapped in the depressions of the openwork mantle of intermediate storage (Statham, 1976) and due to different bouncing intensities as a result of the kinematic energy involved (Bones, 1973). Fine-grained strata evolve from resorting of particles along the scree slope and subsequent covering by "normal" rockfall deposition (Sass and Krautblatter, 2007; Krautblatter and Moser, 2009).

leased by fluvial processes and debris-saturated flows active in the rock face; the short-term intensity of rockfall deposition typically exceeds the deposition during dry periods without frost by a factor of at least $10^{4}$ (Fig. 6).

Nonlinear logistic growth functions of rockfall response in relation to hourly rainfall intensity produce significant high correlations from $R^{2}=0.93$ and 1.00 for all of the eight rockfall nets. The range of correlations in response to 30min rainfall intensities indicates values between $R^{2}=0.93$ and 1.00 , as well. We expect that our models will apply well in large alpine rock wall systems with significant intermediate storage that are, therefore, dominated by secondary rockfalls (Krautblatter and Dikau, 2007; Sass and Krautblatter, 2007). Even if certain adjustments of our models in respect to hydrology, geology and climatic characteristics can be 
necessary in other mountain environments, the principles of the initiation of secondary rockfall events by debris-saturated flows within the rock face remain the same.

These findings influence hazard assessment and risk mitigation strategies. $90 \%$ of rockfall deposition is confined to a small window of time associated with the activity of rainstorms. Hazardous rates of rockfall deposition that endanger human lives and structures correspond with the spatial and temporal occurrence of high short-term rainfall intensities evident on precipitation radar images. Due to the modern achievements of radar technology and software developments such as RADVOR-OP (Radar Supported Near RealTime Precipitation Forecast for Operation Use) of the German Weather Service (DWD) or similar products in other countries, spatial movements and intensity changes of storm cells can be forecast over short spans of time (Hering et al., 2004; Kober and Tafferner, 2009). A combination of the logistic rockfall response functions and thresholds presented in this paper with radar supported precipitation forecast systems could be used to predict intensity, spatial and temporal occurrence of hazardous rockfall events early enough to activate a warning system. Due to the fact that precipitation radar systems are already in use in most mountain ranges in developed countries, such a warning system would have a wide spatial range of applicability. The record of the nearby meteorological station "Hohenpeissenberg" indicates that the moderate warming tendency between 1879 and 1999 coincided with a more than a two-fold increase in the frequency of intense summer rainstorms (DWD, 2001). Further evidence for increasing frequency and magnitude of convective rainstorms has recently been provided by a number of meteorological stations in the Alps and is closely linked to changes in the probability of certain circulation systems that provide air masses rich in water vapour (Fricke and Kaminski, 2002). If the warming tendency continues or accelerates in future, the intensity and frequency of rainstorms is also likely to increase and will trigger an enhanced activity of secondary rockfall events (Krautblatter and Moser, 2006).

Intermediate storage above nets $1 \mathrm{a}, 2$ and 3 receive $0.08 \mathrm{~m}^{3} / \mathrm{yr}$ rockfall prone material per meter lateral extension of the rock wall assuming a back-weathering rate of $0.130 \mathrm{~mm} / \mathrm{a}$ measured by Sass (1998) for Wetterstein limestone close-by. Intermediate storage depletion by rockfall deposition accounted for $0.17 \mathrm{~m}^{3} / \mathrm{yr}$ (net 3), $0.30 \mathrm{~m}^{3} / \mathrm{yr}$ (net 2) and $0.47 \mathrm{~m}^{3} / \mathrm{yr}$ (net 1a). This means that intermediate storage is presently being depleted faster by the activity of secondary rockfall events than refilled by back-weathering activity.

\section{Conclusions}

Small-magnitude rockfalls are difficult to quantify, as their size distribution is not fully covered by laserscanning and their deposits can often not be referenced accurately to a certain time span of deposition (as is the case for large rock- fall deposits). At the same time, small magnitude rockfalls may cause the highest number of (rockfall) casualties in many mountain environments and have an overwhelming importance for sediment budgets. During four years of rockfall measurements, we found out that (i) rockfall intensity is only coupled to rainfall intensity above a certain threshold (here $9-13 \mathrm{~mm} / 30 \mathrm{~min}$ ) and (ii) that the rockfall response to rainfall intensity above the threshold is highly nonlinear. The rockfall deposition during two rainstorms reached previously unreported intensities of up to $300 \mathrm{~kg} /\left(\mathrm{m}^{2} \mathrm{~h}\right)$. We termed these events "secondary rockfall events" as their predominantly fine grain size distribution matches exactly the size composition of intermediate storage in the rock face. A secondary rockfall event can be defined as a short-term mass deposition of fine-grained rockfall material that originates from intermediate storage in the rock wall and is released by fluvial processes and debris-saturated flows active in the rock face; the rockfall deposition occurs during minutes in free falling particle clouds. Secondary rockfall events exceeded the usual annual rockfall deposition by 0.5 to 50 times. Historical descriptions show that secondary rockfall events are likely to account for a double digit number of casualties in the Reintal alone in the last century. We established three nonlinear logistic growth functions for different topographic settings that model rockfall response to shortterm rainfall intensity with correlations from $R^{2}=0.89$ to 0.99. The models account for (i) no rainfall-rockfall coupling at low rainfall intensity, (ii) coupling due to the onset of particle flows in the rock face at a certain rainfall intensity threshold, (iii) secondary rockfall events and (iv) decoupling due to storage depletion at very high rainfall intensities. Nonlinear rock fall response models could be used in combination with radar-supported storm cell forecasts to predict hazardous secondary rockfall events. Data indicate that intermediate storage is presently depleted 2-4 times faster by the activity of secondary rockfall events than refilled by back-weathering. Nevertheless, the capacity of intermediate storage in the study area appears to be sufficient to allow an elevated level of events for at least decades.

Acknowledgements. H. A. Viles, O. Sass, H. Schröder, D. Keller and two anonymous reviewers made important contributions to this article. Special thanks to J. Seltmann of the DWD (Deutscher Wetterdienst) for providing the precipitation radar imagery and supplementary information. This study was conducted as an integral part of the SEDAG (Sediment Cascades in Alpine Geosystems) research bundle funded by the DFG (German Research Association).

Edited by: A. Volkwein

Reviewed by: two anonymous referees 


\section{References}

André, M.-F.: Holocene Rockwall Retreat in Svalbard: A TripleRate Evolution, Earth Surf. Processes, 22, 423-440, 1997.

Becht, M.: Untersuchungen zur aktuellen Reliefentwicklung in alpinen Einzugsgebieten, Münchner Geogr. Abh. Reihe B, 47, 187 pp., 1995.

Berti, M., Genevois, R., Simoni, A., and Tecca, P. R.: Field observation of a debris flow event in the Dolomites, Geomorphology, 29, 265-274, 1999.

Bones, J. G.: Process and sediment size arrangement on high arctic talus slopes, South West Devon Island, N. W. T., Arctic Alpine Res., 5, 29-40, 1973.

Caine, N.: The influence of snow and increased snowfall on contemporaryy geomorphic processes in alpine areas, in: Ecological impacts of snowpack augmentation in San Juan Mountains, Colorado, edited by: Steinoff, H. D., and Ives, J. D., 1976.

Carniel, P. and Scheidegger, A. E.: Morphometry of an Alpine scree slope, Revista Italiana di Geografica, 23, 95-100, 1974.

Dorren, L. K. A.: A review of rockfall mechanics and modelling approaches, Progress in Physical Geography, 26, 69-87, 2003.

Douglas, G. R.: Magnitude Frequency study of Rockfall in Co. Antrim, N. Ireland, Earth Surf. Processes, 5, 123-129, 1980.

DWD: Der langjährige Niederschlagstrend am Hohenpeißenberg: Die Bedeutung von Extremwerten, Global Atmosphere Watch Brief des Deutschen Wetterdienstes, 5, 1-2, 2001.

Erismann, T. H. and Abele, G.: Dynamics of Rockslides and Rockfalls, Springer, Heidelberg, 316 pp., 2001.

Fahey, B. D. and Lefebure, T. H.: The freeze-thaw weathering regime at a section of the Niagara escarpment on Bruce Peninsula, Canada, Earth Surf. Processes, 13, 293-304, 1988.

Fricke, W. and Kaminski, U.: Ist die Zunahme von Starkniederschlägen auf veränderte Wetterlagen zurückzuführen?, GAWBrief des DWD, 12, 1-2, 2002.

Fryxell, F. M. and Horberg, L.: Alpine mudflows at the Grand Teton National Park, Wyoming, Bull. Geol. Soc. Amer., 54, 457-572, 1943.

Gardner, J.: Frequency, magnitude and spatial distribution of mountain rockfalls and rockslides in the Highwood Pass area, Alberta, in: Thresholds in Geomorphology, edited by: Coates, D. R. and Vitek, J. D., Allen \& Unwin, London, 267-295, 1980.

Gardner, J.: Rockfall frequency and distribution in the Highwood Pass area, Canadian Rocky Mountains, Z. Geomorph. N. F., 27, 311-324, 1983.

Glade, T.: Linking debris-flow hazard assessment with geomorphology, Geomorphology, 66, 189-213, 2005.

Hering, A. M., Morel, C., Galli, G., Sénési, P., Ambrosetti, P., and Boscacci, M.: Nowcasting thunderstorms in the Alpine region using a radar based adaptive thresholding scheme, Third European Conference on Radar Meteorology (ERAD), Visby, Sweden, 206-211, 2004.

Hungr, O., Evans, S. G., and Hazzard, J.: Magnitude and frequency of rock falls and rock slides along the main transportation corridors of southwestern British Columbia, Can. Geotech. J., 36, 224-238, 1999.

Keefer, D. K.: Landslides Caused by Earthquakes, Geol. Soc. Am. Bull., 95, 406-421, 1984.

Keefer, D. K.: Investigating Landslides caused by Earthquakes historical review, Surv. Geophys., 23, 473-510, 2002.
Kober, K. and Tafferner, A.: Tracking and nowcasting of convective cells using remote sensing data from radar and satellite, Meteorol. Z., 18, 75-84, 2009.

Krautblatter, M. and Moser, M.: Will we face an increase in hazardous secondary rockfall events in response to global warming in the foreseeable future?, in: Global Change in Mountain Regions, edited by: Price, M. F., Sapiens Publishing, Duncow, 2006.

Krautblatter, M. and Dikau, R.: Towards a uniform concept for the comparison and extrapolation of rockwall retreat and rockfall supply, Geogr. Ann. A, 89, 21-40, 2007.

Krautblatter, M. and Moser, M.: The role of predepositional processes in response to climatic fluctuations in the development of stratified scree deposits (Reintal, German Alps), Salzburger Geographische Abhandlungen, in press, 2009.

Luckman, B. H.: Rockfalls and rockfall inventory data; Some observations from the Surprise Valley, Jasper National Park, Canada., Earth Surf. Proc. Land., 1, 287-298, 1976.

Luckman, B. H.: The measurement of debris movements on alpine talus slopes, Z. Geomorph. N. F., Suppl.-Bd. 29, 117-129, 1978.

Matsuoka, N.: The rate of bedrock weathering by frost action: field measurements and a predictive model, Earth Surf. Proc. Land., 15, 73-90, 1990.

Matznetter, K.: Der Vorgang der Massenbewegungen an Beispielen des Klostertales in Vorarlberg, Geogr. Jahresber. Österreich, 25, 108 pp., 1956.

Nyberg, R.: Geomorphic processes at snowpatch sites in the Abisko Mountains, northern Sweden, Z. Geomorph. N. F., 35, 321-343, 1991.

Rapp, A.: Recent developement in the Mountain Slopes in Kärkevagge and Surroundings, Northern Scandinavia, Geogr. Ann., 42, 1-158, 1960.

Sandersen, F., Bakkehoi, S., Hestnes, E., and Lied, K.: The influence of metereological factors on the initiation of debris flows, rockfalls, rockslides and rockmass stability, in: 7th Int. Symp. on Landslides, edited by: Senneset, K., Rotterdam, 1996.

Sass, O.: Die Steuerung von Steinschlagmenge durch Mikroklima, Gesteinsfeuchte und Gesteinseigenschaften im westlichen Karwendelgebirge, Münchner Geogr. Abh. Reihe B, 29, 1998.

Sass, O. and Krautblatter, M.: Debris flow-dominated and rockfalldominated talus slopes: Genetic models derived from GPR measurements, Geomorphology, 86, 176-192, 2007.

Selby, M. J.: A rock mass strength classification for geomorphic purposes, Z. Geomorph. N. F., 24, 31-51, 1980.

Sommerhoff, G.: Zur spät- und postglazialen Morphodynamik im oberen Rißbachtal, Karwendel, Mitt. Geogr. Ges. München, 62, 89-102, 1977.

Statham, I.: A Scree Slope Rockfall Modell, Earth Surf. Processes, 1, 43-62, 1976.

Wehrle, C.: Das Reintal, Panico Alpinverlag, Koengen, 240 pp., 2004.

Wetzel, K. F.: Abflussbildung während sommerlicher Niederschläge in einem kleinen Einzugsgebiet der nördlichen Kalkalpen, Erdkunde, 34, 161-173, 1994.

Whalley, W. B.: Rockfalls, in: Slope Instability, edited by: Brundsden, D., and Prior, D. B., Wiley \& Sons, London, 217-256, 1984. 